\title{
Mechanism for the Bitter Tasting Potency of Peptides Using $O$-Aminoacyl Sugars as Model Compounds ${ }^{+}$
}

\author{
Masahiro Tamura, Takafumi Mryoshi, Naoko Mori, \\ Keisuke Kinomura, Michihiko Kawaguchi, Norio Ishibashi \\ and Hideo OKAI* \\ Department of Fermentation Technology, Faculty of Engineering. \\ Hiroshima University, Shitami, Saijo-cho, \\ Higashihiroshima 724, Japan \\ Received November 29, 1990
}

\begin{abstract}
In order to study the role of hydrophobicity in bitter peptides, several $O$-aminoacyl sugars, in which amino acids or peptides were attached to the 2 - and 3 -position of methyl $\alpha$-D-glucopyranoside, were synthesized and sensory analyses were carried out. It was found that the bitterness increased as the hydrophobicity of compounds increased, implying that the bitterness receptor recognizes the hydrophobicity of bitter peptides. A structure for the bitterness receptor is also discussed.
\end{abstract}

We have been studying the relationship between the bitterness and chemical structure of peptides by systematically synthesizing numerous model bitter peptides. ${ }^{1-7)}$ The mechanism for the bitterness production of peptides is now clear. Bitter peptides possess two active sites for the bitterness, and we have named these sites as the "binding unit" (BU) and "stimulating unit" (SU). Hydrophobic groups act as BU's while bulky basic groups including an $\alpha$-amino group or hydrophobic groups acts as SU's. The bitterness was pro-

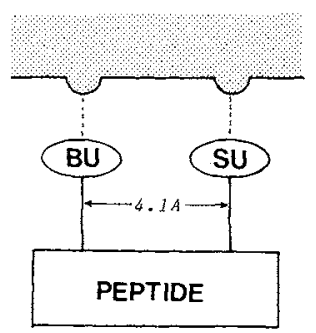

Fig. 1. Bitterness Receptor Model Proposed by Ishibashi et al. ${ }^{6}$ duced when these active units were attached to the corresponding bitter taste determinant. By synthetic studies on the bitterness of cyclodipeptides, the distance between the two sites was estimated to be $4.1 \AA$. $^{6}$ A model of the receptor site is shown in Fig. 1.

Although the mechanism for the bitterness production has been well explained, it is hard to explain the mechanism for bitterness intensity by this model. The receptor site model shown in Fig. 1 is not good enough to help understand how the receptor recognizes the difference between very bitter compounds and not very bitter compounds. Phenylalanine possesses a bitterness only 0.3 times that of caffeine. On the other hand, the bitter potency of phenylalanine oligomers increases as the number of phenylalanine residues increases. As we reported in the previous paper, the bitterness of Phe-Phe was 0.83 times that of caffeine, while Phe-Phe-Phe produced a bitterness eight times greater. ${ }^{2,3)}$ These results show that the bitter potency of phenylalanine was

+ Studies on Flavored Peptides. VIII.

* To whom enquiries should be addressed.

The abbreviations recommended by the IUPAC-IUB Commission of Biochemical Nomenclature [J. Biol. Chem., 274, 977 (1972)] were used. Amino acids except for glycine are of the L-configuration unless otherwise noted.

Abbreviations: DCC, dicyclohexylcarbodiimide; DCUrea, $N, N^{\prime}$-dicyclohexylurea. 
easily intensified by up to 10-20 times by increasing the phenylalanine residues. These results told us that the hydrophobicity of the whole molecule is an important key for bitterness potency. The phenylalanine tetramer, which was expected to produce stronger bitterness than that of Phe, Phe-Phe or Phe-PhePhe, was insoluble in water.

In order to study the relationship between the bitter potency and hydrophobicity of the molecule, we needed compounds which possessed a high hydrophobicity. However, as we have already mentioned, oligomers of hydrophobic amino acids easily became insoluble in water. We had to find the right compounds, which had both high hydrophobicity and solubility in water, for this study. $O$-Aminoacyl sugars developed in our laboratory ${ }^{8,9}$ were thought to be the best compounds to solve this problem. Even if hydrophobic amino acids or peptides were introduced into the 2,3-positions of methyl $\alpha$-D-glucopyranoside, this aminoacyl sugar would still possess solubility because of free hydroxyl groups at the 4,6-positions. Furthermore, two hydrophobic amino acids or peptides could get closer because they were introduced into the neighboring hydroxyls. Therefore, we expected these compounds to produce strong bitterness with high solubility in water.

We introduced amino acids and peptides of various hydrophobicity into the 2,3-position of methyl $\alpha$-D-glucopyranoside and studied the bitterness potency. We also introduced three peptides (Phe-Phe-Gly-Gly-, Phe-Gly-PheGly, and Phe-Gly-Gly-Phe) into the sugar. The tastes of these peptides, possessing the same hydrophobicity, could show a mechanism for the bitterness potency. In this paper, we will discuss the relationship between the bitter potency and hydrophobicity of $O$-aminoacyl sugars. We will also propose a model of a bitterness receptor site which can recognize hydrophobicity.

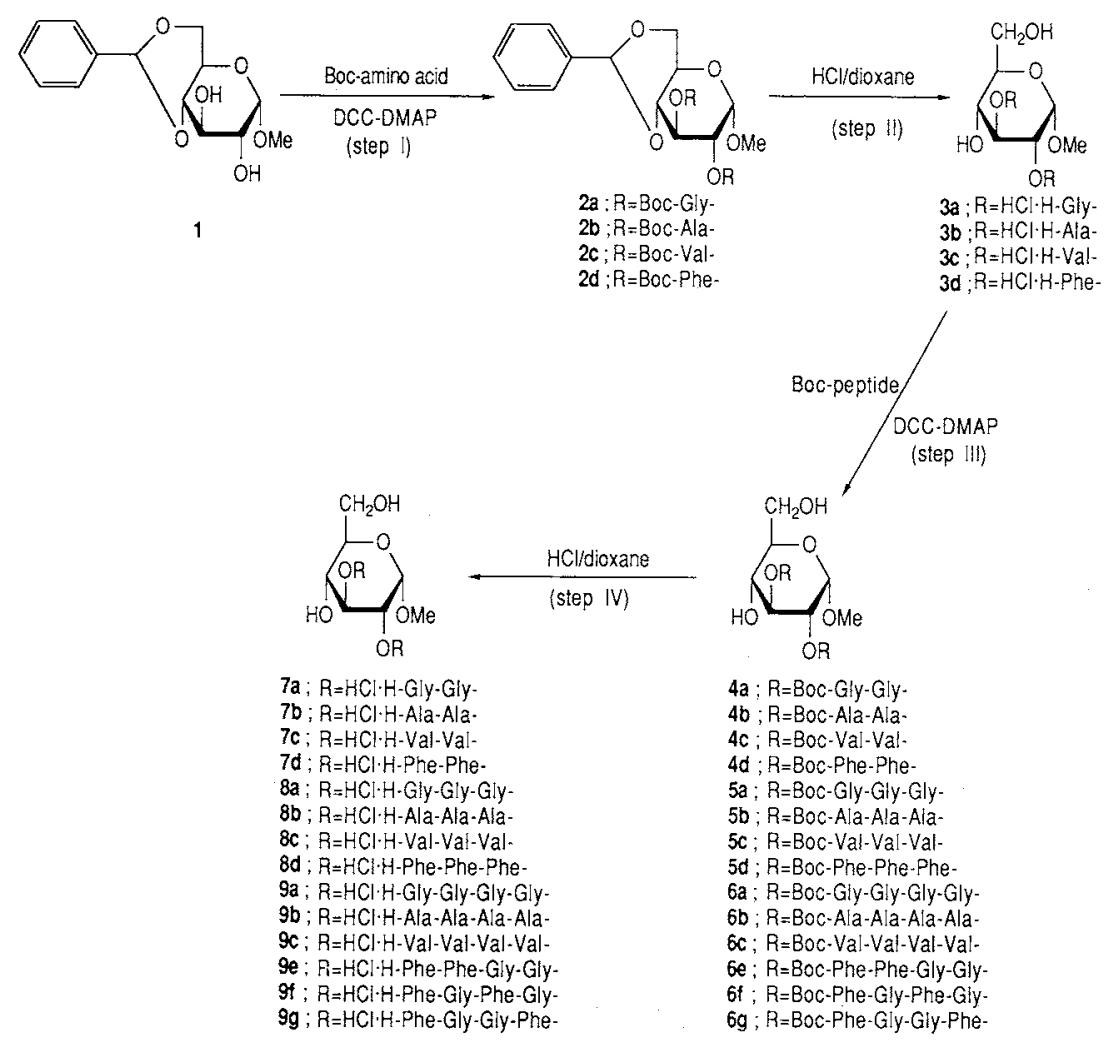

Fig. 2. Synthesis of $O$-Aminoacyl Sugars. 


\section{Experimental}

(I) Synthesis of O-Aminoacyl Sugars. The synthetic route for the $O$-aminoacyl sugars is shown in Fig. 2. Yields and physical constants of the synthesized $O$-aminoacyl sugars and intermediates are listed in Table $\mathrm{I}$.

General Information. All the melting points were uncorrected. TLC was performed on Merck Silica gel G with four solvent systems: hexane-ethyl acetate $(2: 1, v / v)$ as $R f^{1}, 1$-butanol-acetic acid-pyridine-water $(4: 1: 1: 2, \mathrm{v} / \mathrm{v})$ as $R f^{2}$, chloroform-methanol $\left(9: 1, \mathrm{v} / \mathrm{v}\right.$ as $R f^{3}$, and chloroform-methanol $(5: 1, v / v)$ as $R f^{4}$. For the detection of compounds with free amino groups, a $0.2 \%$ ninhydrin solution in methanol was used, and for protected amino compounds, the chlorine-o-tolidine method ${ }^{10.113}$ was used. The methyl $\alpha$-D-glucoside derivatives were detected by $0.2 \%$ o-orcinol in $1 \mathrm{M} \mathrm{H}_{2} \mathrm{SO}_{4}$. Optical rotation was measured on a Union PM 101 polarimeter, and micro-analyses were carried out by Sanshin Chemical Industrial Co., Ltd., Yamaguchi. All analytical results were within $\pm 0.15 \%$ of the theoretical values.

Methyl 4,6-O-benzylidene-2,3-di-O-[N-(t-butoxycarbon$y$ l)-L-alanyl]- $\alpha$-D-glucopyranoside ( $\mathbf{2} \mathbf{b}$, step $I$ ). To an icecooled solution of $1(1.41 \mathrm{~g}, 5 \mathrm{mmol})$ and $N$ - $(t$-butoxycarbonyl)-L-alanine $(2.27 \mathrm{~g}, 12 \mathrm{mmol})$ in $\mathrm{CH}_{2} \mathrm{Cl}_{2}(30 \mathrm{ml})$

Table I. Physical Contents of Synthetic O-Aminoacyl Sugars

\begin{tabular}{|c|c|c|c|c|c|}
\hline Compound & $\begin{array}{l}\text { Yield } \\
(\%)\end{array}$ & $\begin{array}{l}\mathrm{mp} \\
(\mathrm{)}\end{array}$ & $\begin{array}{c}{[x]_{\mathrm{D}}^{25}(c, \text { solvent })} \\
()\end{array}$ & $\begin{array}{l}\text { Rf Value } \\
\text { on TLC }\end{array}$ & Formula \\
\hline $2 a$ & 84 & $102-105$ & $+29(c 1.0, \mathrm{MeOH})$ & $R f^{3}=0.97$ & $\mathrm{C}_{21} \mathrm{H}_{36} \mathrm{~N}_{2} \mathrm{O}_{12}$ \\
\hline $2 b$ & 82 & $91-95$ & $+7(c 1.0, \mathrm{MeOH})$ & $R f^{1}=0.49$ & $\mathrm{C}_{23} \mathrm{H}_{40} \mathrm{~N}_{2} \mathrm{O}_{12}$ \\
\hline $2 c$ & 78 & $160-163$ & $+18(c 1.0, \mathrm{MeOH})$ & $R f^{1}=0.66$ & $\mathrm{C}_{27} \mathrm{H}_{48} \mathrm{~N}_{2} \mathrm{O}_{12}$ \\
\hline $2 d$ & 84 & $163-164$ & $+22(c 0.5, \mathrm{MeOH})$ & $R f^{1}=0.51$ & $\mathrm{C}_{35} \mathrm{H}_{48} \mathrm{~N}_{2} \mathrm{O}_{12}$ \\
\hline $3 \mathbf{a}$ & 93 & $155-157(\mathrm{dec})$ & $+87\left(c 1.0, \mathrm{H}_{2} \mathrm{O}\right)$ & $R f^{2}=0.51$ & $\mathrm{C}_{11} \mathrm{H}_{22} \mathrm{~N}_{2} \mathrm{O}_{8} \mathrm{Cl}_{2} \cdot 1 / 6 \mathrm{H}_{2} \mathrm{O}$ \\
\hline $\mathbf{3 b}$ & 91 & $121-124(\mathrm{dec})$ & $+85\left(c 1.0, \mathrm{H}_{2} \mathrm{O}\right)$ & $R f^{2}=0.62$ & $\mathrm{C}_{13} \mathrm{H}_{26} \mathrm{~N}_{2} \mathrm{O}_{8} \mathrm{Cl}_{2} \cdot \mathrm{i} / 4 \mathrm{H}_{2} \mathrm{O}$ \\
\hline $3 \mathbf{c}$ & 94 & $108-110(\mathrm{dec})$ & $+82\left(c 1.0, \mathrm{H}_{2} \mathrm{O}\right)$ & $R f^{2}=0.74$ & $\mathrm{C}_{17} \mathrm{H}_{34} \mathrm{~N}_{2} \mathrm{O}_{8} \mathrm{Cl}_{2} \cdot 3 / 10 \mathrm{H}_{2} \mathrm{O}$ \\
\hline 3d & 93 & $151-154(\mathrm{dec})$ & $+60\left(c 1.0, \mathrm{H}_{2} \mathrm{O}\right)$ & $R f^{2}=0.85$ & $\mathrm{C}_{25} \mathrm{H}_{34} \mathrm{~N}_{2} \mathrm{O}_{8} \mathrm{Cl}_{2} \cdot 1 / 5 \mathrm{H}_{2} \mathrm{O}$ \\
\hline $4 \mathbf{a}$ & 85 & $130-131$ & $+50\left(c 1.0, \mathrm{CHCl}_{3}\right)$ & $R f^{4}=0.81$ & $\mathrm{C}_{25} \mathrm{H}_{42} \mathrm{~N}_{4} \mathrm{O}_{14}$ \\
\hline $4 \mathrm{~b}$ & 82 & $96-97$ & $+50(c 1.0, \mathrm{MeOH})$ & $R f^{4}=0.67$ & $\mathrm{C}_{29} \mathrm{H}_{50} \mathrm{~N}_{4} \mathrm{O}_{14}$ \\
\hline $4 c$ & 76 & $99-110$ & $+15(c 1.0, \mathrm{MeOH})$ & $R f^{4}=0.80$ & $\mathrm{C}_{37} \mathrm{H}_{66} \mathrm{~N}_{4} \mathrm{O}_{14}$ \\
\hline 4d & 80 & $149-150$ & $+25\left(c 1.0, \mathrm{CHCl}_{3}\right)$ & $R f^{5}=0.34$ & $\mathrm{C}_{53} \mathrm{H}_{66} \mathrm{~N}_{4} \mathrm{O}_{14}$ \\
\hline $\mathbf{5 a}$ & 76 & $92-95(\mathrm{dec})$ & $+54(c 1.0, \mathrm{MeOH})$ & $R f^{3}=0.46$ & $\mathrm{C}_{29} \mathrm{H}_{48} \mathrm{~N}_{6} \mathrm{O}_{16}$ \\
\hline $\mathbf{5 b}$ & 78 & 114116 & $-21(c 1.0, \dot{\mathrm{MeOH}})$ & $R f^{3}=0.63$ & $\mathrm{C}_{35} \mathrm{H}_{60} \mathrm{~N}_{6} \mathrm{O}_{16}$ \\
\hline $5 \mathbf{c}$ & 76 & $207-209(\mathrm{dec})$ & $-9(c 1.0, \mathrm{MeOH})$ & $R f^{3}=0.73$ & $\mathrm{C}_{47} \mathrm{H}_{84} \mathrm{~N}_{6} \mathrm{O}_{16}$ \\
\hline $5 d$ & 82 & $99-101$ & $+6\left(c 1.0, \mathrm{CHCl}_{3}\right)$ & $R f^{3}=0.62$ & $\mathrm{C}_{71} \mathrm{H}_{34} \mathrm{~N}_{6} \mathrm{O}_{16}$ \\
\hline $6 a$ & 72 & $75-77(\mathrm{dec})$ & $+36(c 0.5, \mathrm{MeOH})$ & $R f^{3}=0.23$ & $\mathrm{C}_{33} \mathrm{H}_{54} \mathrm{~N}_{8} \mathrm{O}_{18}$ \\
\hline $6 \mathrm{~b}$ & 75 & $169-173$ & $-30(c 0.9, \mathrm{MeOH})$ & $R f^{3}=0.60$ & $\mathrm{C}_{41} \mathrm{H}_{70} \mathrm{~N}_{8} \mathrm{O}_{18}$ \\
\hline $6 \mathrm{c}$ & 72 & $177-179(\mathrm{dec})$ & $-32(c 1.0, \mathrm{MeOH})$ & $R f^{2}=0.66$ & $\mathrm{C}_{57} \mathrm{H}_{102} \mathrm{~N}_{8} \mathrm{O}_{18}$ \\
\hline $6 e$ & 68 & $120-125$ & $+9\left(c 1.0, \mathrm{CHCl}_{3}\right)$ & $R f^{4}=0.77$ & $\mathrm{C}_{61} \mathrm{H}_{78} \mathrm{~N}_{8} \mathrm{O}_{18}$ \\
\hline $6 f$ & 71 & $104-105$ & $+28(c 0.5, \mathrm{MeOH})$ & $R f^{3}=0.51$ & $\mathrm{C}_{61} \mathrm{H}_{78} \mathrm{~N}_{8} \mathrm{O}_{18}$ \\
\hline $6 \mathrm{~g}$ & 66 & $100-103$ & $-21(c 1.0, \mathrm{MeOH})$ & $R f^{3}=0.71$ & $\mathrm{C}_{61} \mathrm{H}_{78} \mathrm{~N}_{8} \mathrm{O}_{18}$ \\
\hline $7 \mathbf{a}$ & 92 & $137-142(\mathrm{dec})$ & $+73\left(c 1.0, \mathrm{H}_{2} \mathrm{O}\right)$ & $R f^{4}=0.03$ & $\mathrm{C}_{15} \mathrm{H}_{28} \mathrm{~N}_{4} \mathrm{O}_{10} \mathrm{Cl}_{2} \cdot 1 / 4 \mathrm{H}_{2} \mathrm{O}$ \\
\hline $7 \mathrm{~b}$ & 89 & $210(\mathrm{dec})$ & $+21(c 1.0, \mathrm{MeOH})$ & $R f^{2}=0.42$ & $\mathrm{C}_{19} \mathrm{H}_{36} \mathrm{~N}_{4} \mathrm{O}_{10} \mathrm{Cl}_{2} \cdot 1 / 4 \mathrm{H}_{2} \mathrm{O}$ \\
\hline $7 c$ & 92 & $181-183(\mathrm{dec})$ & $+27\left(c 1.0, \mathrm{H}_{2} \mathrm{O}\right)$ & $R f^{2}=0.83$ & $\mathrm{C}_{27} \mathrm{H}_{52} \mathrm{~N}_{4} \mathrm{O}_{10} \mathrm{Cl}_{2} \cdot 1 / 5 \mathrm{H}_{2} \mathrm{O}$ \\
\hline $7 d$ & 94 & 125 & $+54(c 1.0, \mathrm{MeOH})$ & $R f^{2}=0.77$ & $\mathrm{C}_{43} \mathrm{H}_{52} \mathrm{~N}_{4} \mathrm{O}_{10} \mathrm{Cl}_{2} \cdot 1 / 6 \mathrm{H}_{2} \mathrm{O}$ \\
\hline $\mathbf{8 a}$ & 95 & $124-127(\mathrm{dec})$ & $+51\left(c 1.0, \mathrm{H}_{2} \mathrm{O}\right)$ & $R f^{2}=0.65$ & $\mathrm{C}_{19} \mathrm{H}_{34} \mathrm{~N}_{6} \mathrm{O}_{12} \mathrm{Cl}_{2} \cdot 3 / 10 \mathrm{H}_{2} \mathrm{O}$ \\
\hline $\mathbf{8 b}$ & 91 & $161-168(\mathrm{dec})$ & $+7(c 1.0, \mathrm{MeOH})$ & $R f^{2}=0.54$ & $\mathrm{C}_{25} \mathrm{H}_{46} \mathrm{~N}_{6} \mathrm{O}_{12} \mathrm{Cl}_{2} \cdot 1 / 4 \mathrm{H}_{2} \mathrm{O}$ \\
\hline $8 c$ & 89 & $207-209(\mathrm{dec})$ & $-9(c 1.0, \mathrm{MeOH})$ & $R f^{3}=0.73$ & $\mathrm{C}_{37} \mathrm{H}_{70} \mathrm{~N}_{6} \mathrm{O}_{12} \mathrm{Cl}_{2} \cdot 1 / 6 \mathrm{H}_{2} \mathrm{O}$ \\
\hline 8d & 88 & $118-120$ & $+29(c 1.0, \mathrm{MeOH})$ & $R f^{3}=0.33$ & $\mathrm{C}_{61} \mathrm{H}_{70} \mathrm{~N}_{6} \mathrm{O}_{12} \mathrm{Cl}_{2} \cdot 1 / 4 \mathrm{H}_{2} \mathrm{O}$ \\
\hline $9 \mathbf{a}$ & 91 & $76-77(\mathrm{dec})$ & $+23\left(c 1.0, \mathrm{H}_{2} \mathrm{O}\right)$ & $R f^{2}=0.27$ & $\mathrm{C}_{23} \mathrm{H}_{40} \mathrm{~N}_{8} \mathrm{O}_{14} \mathrm{Cl}_{2} \cdot 1 / 5 \mathrm{H}_{2} \mathrm{O}$ \\
\hline $9 \mathrm{~b}$ & 93 & $195-197(\mathrm{dec})$ & $+35(c 1.0, \mathrm{MeOH})$ & $R f^{2}=0.51$ & $\mathrm{C}_{31} \mathrm{H}_{56} \mathrm{~N}_{8} \mathrm{O}_{14} \mathrm{Cl}_{2} \cdot 1 / 4 \mathrm{H}_{2} \mathrm{O}$ \\
\hline $9 \mathrm{c}$ & 90 & $195-199(\mathrm{dec})$ & $-12\left(c 1.0, \mathrm{H}_{2} \mathrm{O}\right)$ & $R f^{2}=0.89$ & $\mathrm{C}_{47} \mathrm{H}_{88} \mathrm{~N}_{8} \mathrm{O}_{14} \mathrm{Cl}_{2} \cdot 1 / 5 \mathrm{H}_{2} \mathrm{O}$ \\
\hline $9 e$ & 93 & $186(\mathrm{dec})$ & $+30(c 1.0, \mathrm{MeOH})$ & $R f^{2}=0.73$ & $\mathrm{C}_{51} \mathrm{H}_{64} \mathrm{~N}_{8} \mathrm{O}_{14} \mathrm{Cl}_{2} \cdot 1 / 4 \mathrm{H}_{2} \mathrm{O}$ \\
\hline 9f & 91 & $121-123(\mathrm{dec})$ & $+44\left(c 1.0, \mathrm{H}_{2} \mathrm{O}\right)$ & $R f^{2}=0.86$ & $\mathrm{C}_{51} \mathrm{H}_{64} \mathrm{~N}_{8} \mathrm{O}_{14} \mathrm{Cl}_{2} \cdot 1 / 5 \mathrm{H}_{2} \mathrm{O}$ \\
\hline $9 \mathrm{~g}$ & 90 & $140-145(\mathrm{dec})$ & $+63\left(c 1.0, \mathrm{H}_{2} \mathrm{O}\right)$ & $R f^{2}=0.86$ & $\mathrm{C}_{51} \mathrm{H}_{64} \mathrm{~N}_{8} \mathrm{O}_{14} \mathrm{Cl}_{2} \cdot 1 / 4 \mathrm{H}_{2} \mathrm{O}$ \\
\hline
\end{tabular}

a $R f^{1}$, hexane-ethyl acetate $(2: 1, \mathrm{v} / \mathrm{v}) ; R f^{2}, 1$-butanol-acetic acid-pyridine-water $(4: 1: 1: 2, \mathrm{v} / \mathrm{v}) ; R f^{3}$, chloroform-methanol $(9: 1, \mathrm{v} / \mathrm{v}) ; R f^{4}$, chloroform-methanol $(5: 1, \mathrm{v} / \mathrm{v})$. 
was added $\mathrm{DCC}(2.70 \mathrm{~g}, 13.1 \mathrm{mmol})$. The mixture was stirred at $0^{\circ} \mathrm{C}$ for $2 \mathrm{hr}$ and then at room temperature overnight. After the resultant DCUrea had been removed, the filtrate was evaporated. The residue was dissolved in ethyl acetate, washed with $4 \% \mathrm{NaHCO}_{3}$ and water, dried over anhydrous $\mathrm{Na}_{2} \mathrm{SO}_{4}$ and evaporated. This crude product was applied to a column of silica gel using hexaneethyl acetate $(4: 1)$ as the eluent. Fractions containing the product were collected and evaporated, compound $\mathbf{2 b}$ being solidified from ether-hexane.

Methyl 2,3-di-O-(L-alanyl)- $\alpha$-D-glucopyranoside dihydrochloride (3b, step II). Compound $2 \mathrm{~b}(2.15 \mathrm{~g}, 4 \mathrm{mmol})$ was dissolved in $4 \mathrm{~N}$ hydrogen chloride in ethyl acetate $(40 \mathrm{ml})$ and formic acid $(40 \mathrm{ml})$. The solution was allowed to stand at room temperature for $4 \mathrm{hr}$ and then evaporated. The addition of ether gave a white powder of $\mathbf{3 b}$, which was recrystallized from methanol-ethyl acetate.

Methyl 2,3-di-O-[N-(t-butoxycarbonyl)-L-alanyl-L-alanyl-L-alanyl-L-alanyl]- $\alpha$-D-glucopyranoside $(\mathbf{6} \mathbf{b}$, step III). To an ice-cooled solution of $3 \mathrm{~b}(1.23 \mathrm{~g}, 3 \mathrm{mmol}), N-(t-$ butoxycarbonyl)-L-alanyl-L-alanyl-L-alanine $(2.39 \mathrm{~g}, \quad 7.2$ $\mathrm{mmol})$ and 1 -hydroxybenzotriazole $(0.81 \mathrm{~g}, 6 \mathrm{mmol})$ in DMF $(10 \mathrm{ml})$ was added DCC $(1.63 \mathrm{~g}, 7.9 \mathrm{mmol})$. The mixture was stirred at $0^{\circ}$ for $2 \mathrm{hr}$ and then at room temperature overnight. After removing DCUrea, the filtrate was evaporated. The resultant residue was dissolved in ethyl acetate, washed with $4 \% \mathrm{NaHCO}_{3}$ and water, dried over anhydrous $\mathrm{Na}_{2} \mathrm{SO}_{4}$ and evaporated. Compound $\mathbf{6 b}$ was solidified from ether-petroleum ether.

Methyl 2,3-di-O-(L-alanyl-L-alanyl-L-alanyl-L-alanyl $)-\alpha-$ D-glucopyranoside dihydrochloride $(\mathbf{9 b}$, step IV). Compound $6 \mathrm{~b}(1.93 \mathrm{~g}, 2 \mathrm{mmol})$ was dissolved in $4 \mathrm{~N}$ hydrogen chloride in dioxane $(30 \mathrm{ml})$. The solution was allowed to stand at room temperature for $3 \mathrm{hr}$ and then evaporated, before the resultant oily residue was solidified from ethyl acetate. All other $O$-aminoacyl sugars were prepared by the similar procedure.
(2) Sensory analysis. For all the synthesized $O$ aminoacyl sugars and peptides, the features and intensity of taste were evaluated by 4 to 5 panels and are presented as the threshold concentration (TV). Caffeine was used as an index compound for bitterness, the procedure for sensory testing having been described in detail in the previous report. ${ }^{11}$

\section{Results and Discussion}

\section{(1) O-Aminoacyl sugars and peptides producing} sweetness or tastelessness

The results of a sensory analysis of the $O$ aminoacyl sugars and peptides composed of glycine residues are shown in Table II. Compound $\mathbf{3 a}$ and Gly produced sweetness, the sweetness of $\mathbf{3 a}$ being about twice that of sucrose. The other $O$-aminoacyl sugars and peptides containing glycine residues were tasteless. We calculated the hydrophobicity of the side chains of the peptide moieties according to the procedure of Nozaki and Tanford, ${ }^{12}$ which was zero for all the peptides composed of glycine residues.

As shown in Table III, the $O$-aminoacyl sugars and peptides composed of alanine residues also produced sweetness or no taste. The sweetness of $\mathbf{3 b}$ was 16 times stronger than that of sucrose at the threshold value. The degree of hydrophobicity of the side chains of alanine in the $O$-aminoacyl sugars and peptides increased as the number of alanine residues increased. The most hydrophobic alanine peptide contained in the $O$-aminoacyl sugars was Ala-Ala-Ala-Ala (the degree of

Table II. Sensory Analysis of O-Aminoacyl Sugars and Peptides Composed of Glycine Residues

\begin{tabular}{lcccc}
\hline Compound & $\begin{array}{c}\text { Number of amino } \\
\text { acid residues }\end{array}$ & Taste & TV (mM $)^{a}$ & $\begin{array}{c}\text { Hydrophobicity of the peptide } \\
\text { moiety } \Sigma \Delta f(\mathrm{kcal} / \mathrm{mol})^{10}\end{array}$ \\
\hline $\mathbf{3 a}$ & 2 & Sweet & 2.1 & 0 \\
$\mathbf{7 a}$ & 4 & Tasteless & - & 0 \\
$\mathbf{8 a}$ & 6 & Tasteless & - & 0 \\
$\mathbf{9 a}$ & 8 & Tasteless & - & 0 \\
Gly & 1 & Sweet & 38 & 0 \\
Gly-Gly & 2 & Tasteless & - & 0 \\
Gly-Gly-Gly & 3 & Tasteless & - & 0 \\
Gly-Gly-Gly-Gly & 4 & Tasteless & - & 0 \\
\hline
\end{tabular}

a Threshold value. 
Table III. Sensory Analysis of $O$-Aminoacyl Sugars and Peptides Composed of Alanine Residues

\begin{tabular}{|c|c|c|c|c|}
\hline Compound & $\begin{array}{l}\text { Number of amino } \\
\text { acid residues }\end{array}$ & Taste & $T V(\mathrm{~mm})^{a}$ & $\begin{array}{l}\text { Hydrophobicity of the peptide } \\
\text { moiety } \Sigma \Delta f(\mathrm{kcal} / \mathrm{mol})^{10)}\end{array}$ \\
\hline $\mathbf{3 b}$ & 2 & Sweet & 0.32 & 1.46 \\
\hline $7 b$ & 4 & Sweet $>$ bitter & - & 2.92 \\
\hline $8 b$ & 6 & Tasteless & - & 4.38 \\
\hline $9 \mathrm{~b}$ & 8 & Tasteless & - & 5.84 \\
\hline Ala & 1 & Sweet & 25 & 0.75 \\
\hline Ala-Ala & 2 & Sweet & 6.0 & 1.46 \\
\hline Ala-Ala-Ala & 3 & Sweet & 3.0 & 2.19 \\
\hline Ala-Ala-Ala-Ala & 4 & Tasteless & - & 2.92 \\
\hline
\end{tabular}

a Threshold value.

Table IV. Sensory Analysis of O-Aminoacyl Sugars and Peptides Composed OF VALine Residues

\begin{tabular}{lclccc}
\hline Compound & $\begin{array}{c}\text { Number of amino } \\
\text { acid residues }\end{array}$ & Taste & $T V(\mathrm{~mm})^{a}$ & $R_{\text {caf }}{ }^{b}$ & $\begin{array}{c}\text { Hydrophobicity of the peptide } \\
\text { moiety } \sum \Delta f(\mathrm{kcal} / \mathrm{mol})^{10)}\end{array}$ \\
\hline $\mathbf{3 c}$ & 2 & Sweet & 0.41 & - & 3.38 \\
$\mathbf{7 c}$ & 4 & Bitter & 0.25 & 4 & 6.76 \\
$\mathbf{8 c}$ & 6 & Bitter & 0.10 & 10 & 10.14 \\
$9 \mathbf{9}$ & 8 & Bitter & 0.05 & 20 & 13.52 \\
Val & 1 & Sweet $>$ bitter & 19 & - & 1.69 \\
Val-Val & 2 & Umami & 25 & - & 3.38 \\
Val-Val-Val & 3 & Bitter & 4.5 & 0.2 & 6.07 \\
Val-Val-Val-Val & 4 & Bitter & 2 & 0.5 & 6.76 \\
\hline
\end{tabular}

a Threshold value.

${ }^{b}$ Bitter taste potency compared with the threshold value of caffeine. $R_{\text {caf }}$ of caffeine is 1.0 .

c Monosodium glutamate (MSG)-like taste.

hydrophobicity of two alanine tetramers was $5.84 \mathrm{kcal} / \mathrm{mol}$ ). Since this $O$-aminoacyl sugar did not produce any bitterness, the bitterness seemed to require higher hydrophobicity than this peptide offered.

\section{(2) O-Aminoacyl sugars and peptides producing} bitterness

First, we prepared several $O$-aminoacyl sugars and peptides composed of valine residues, the results of the sensory analysis being listed in Table IV. Compound $\mathbf{3 c}$, composed of two valine residues, produced sweetness which contained very weak bitterness. The hydrophobicity of one valine residue $(\Sigma \Delta f=1.69$ $\mathrm{kcal} / \mathrm{mol}$ ) was lower than that of the alanine tetramer $(\Sigma \Delta f=2.92 \mathrm{kcal} / \mathrm{mol})$, valine producing the sweetness and bitterness by itself.
Compound 7c, containing two Val-Val peptides, produced bitterness four times stronger than that of caffeine, showing that a hydrophobicity higher than that from one valine side chain was necessary to produce bitterness. Compound $\mathbf{7 c}$ produced a stronger bitterness than that of Val-Val-Val-Val, the hydrophobicity in the side chains being the same as that of 7c. As we described in the introduction section, two amino acid or peptide residues can be very close by being introduced to the 2 and 3-positions of methyl $\alpha$ D-glucopyranoside, which might be the reason for $7 \mathrm{c}$ producing a stronger bitterness than that of Val-Val-Val-Val. We will show next other evidence of how the introduction of amino acids or peptides into the 2 and 3position of methyl $\alpha$-D-glucopyranoside en- 
Table V. Sensory Analysis of O-Aminoacyl Sugars and Peptides Composed of Phenylalanine Residues

\begin{tabular}{lccccc}
\hline Compound & $\begin{array}{c}\text { Number of amino } \\
\text { acid residues }\end{array}$ & Taste & $T V(\mathrm{~mm})^{a}$ & $R_{\text {caf }}{ }^{b}$ & $\begin{array}{c}\text { Hydrophobicity of the peptide } \\
\text { moiety } \Sigma \Delta f(\mathrm{kcal} / \mathrm{mol})^{10)}\end{array}$ \\
\hline 3d & 2 & Bitter & 0.05 & 20 & 5.30 \\
7d & 4 & Bitter & 0.003 & 333 & 10.60 \\
8d & 6 & Bitter & 0.002 & 500 & 15.90 \\
Phe & 1 & Bitter & 19 & 0.05 & 2.65 \\
Phe-Phe & 2 & Bitter & 1.2 & 0.8 & 5.30 \\
Phe-Phe-Phe & 3 & Bitter & 0.2 & 5 & 7.95 \\
\hline
\end{tabular}

Threshold value.

b Bitter taste potency by comparing with the threshold value of caffeine. $R_{\text {caf }}$ of caffeine is 1.0 .

hances the bitterness.

$O$-Aminoacyl sugars composed of phenylalanine, whose side chain possesses a higher hydrophobicity than that of valine, produced very strong bitterness. Compound $\mathbf{3 d}$, containing two phenylalanine residues, produced bitterness 20 times stronger than that of caffeine (see Table V). The bitterness potency of $\mathbf{3 d}$ was the same as that of BPIa (Arg-Gly-Pro-ProPhe-Ile-Val) isolated from proteolytic $\beta$-casein hydrolyzate. ${ }^{13-15)}$ The degree of hydrophobicity of the side chains of seven amino acids contained in BPIa is $13.24 \mathrm{kcal} / \mathrm{mol}$. Although the degree of hydrophobicity of the side chains in 3d $(\Sigma \Delta f=5.30 \mathrm{kcal} / \mathrm{mol})$ was much lower than that of BPIa, 3d produced the same bitterness as the of BPIa. This is the typical piece of evidence that bitterness due to the hydrophobicity of the side chains was enhanced by them being introduced into the neighboring positions of methyl $\alpha$-D-glucopyranoside.

The bitter potency of an $O$-aminoacyl sugar composed of two Phe-Phe residues (7d) was more than 15 times that of $\mathbf{3 d}$ containing four Phe-Phe dipeptides at the 2- and 3-position. The bitterness of $7 \mathbf{d}$ reached the same level of that of strychnine, showing that the bitterness was markedly enhanced by increasing the hydrophobicity of the neighboring positions of methyl $\alpha$-D-glucopyranoside. The bitter intensity of Phe-Phe is only at the same level as that of caffeine. We then prepared an $O$-aminoacyl sugar composed of two Phe-Phe-Phe residues, expecting that $\mathbf{8 d}$ would produce the strongest bitterness of all. However, $\mathbf{8 d}$ produced bitterness $\left(R_{\text {caf }}=500\right)$ almost the same as that of $7 \mathbf{d}$, probably because compound $\mathbf{8 d}$ was too big to get into the bitterness receptor so that the receptor could not recognize the full hydrophobicity of $\mathbf{8 d}$.

(3) Bitterness of $O$-aminoacyl sugars composed of glycine and phenylalanine

As already discussed, methyl 2,3-di- $O$ (phenylalanyl-phenylalanyl)- $\alpha-D-$ glucopyranoside (7d) produced strong bitterness the same as that of strychnine. We conclude that $\mathbf{7 d}$ produced such a strong bitterness because two Phe-Phe residues were located at the 2- and 3-position of methyl $\alpha$-D-glucopyranoside. We also conclude that the bitter taste receptor might have recognized the hydrophobicity of the whole molecule (the bitter intensity increases at the hydrophobicity increases).

Table VI shows the result of a sensory analysis of the $O$-aminoacyl sugars composed of glycine and phenylalanine. All the compounds produced bitterness as the same level. In this series, hydrophobic groups (the phenyl groups of $\mathrm{Phe}$ ) are located at various position. If the bitterness receptor recognizes hydrophobic groups at a specified position, such a result as shown in Table VI would not be obtained. This result clearly shows that the bitterness receptor recognizes the hydrophobicity of the whole molecule. 
Table VI. Sensory Analysis of O-Aminoacyl Sugars and Peptides Composed of Glycine and Phenylalanine Residues

\begin{tabular}{lccccc}
\hline Compound & $\begin{array}{c}\text { Number of amino } \\
\text { acid residues }\end{array}$ & Taste & $T V(\mathrm{~mm})^{a}$ & $R_{\text {caf }}{ }^{b}$ & $\begin{array}{c}\text { Hydrophobicity of the peptide } \\
\text { moiety } \Sigma \Delta f(\mathrm{kcal} / \mathrm{mol})^{10\}}\end{array}$ \\
\hline $\mathbf{9}$ & 8 & Bitter & 0.0047 & 213 & 10.60 \\
$\mathbf{9 f}$ & 8 & Bitter & 0.0058 & 172 & 10.60 \\
$\mathbf{9 g}$ & 8 & Bitter & 0.0029 & 340 & 10.60 \\
Phe-Phe-Gly-Gly & 4 & Bitter & 3.0 & 0.3 & 5.30 \\
Phe-Gly-Phe-Gly & 4 & Bitter & 0.3 & 3.3 & 5.30 \\
Phe-Gly-Gly-Phe & 4 & Bitter & 0.12 & 8.3 & 5.30 \\
\hline
\end{tabular}

a Threshold value.

${ }^{b}$ Bitter taste potency by comparing with the threshold value of caffeine. $R_{\text {caf }}$ of caffeine is 1.0 .

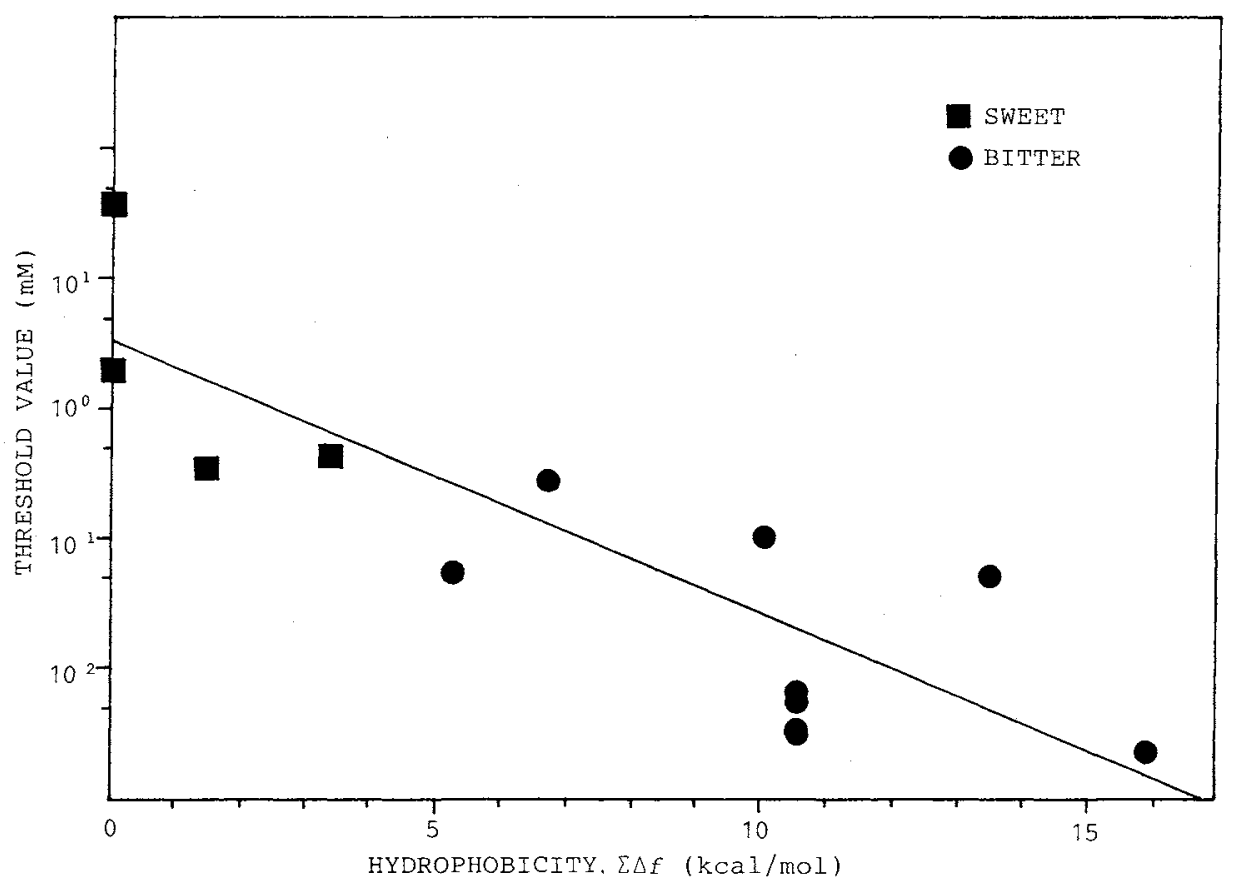

Fig. 3. Correlation between the Threshold Value of Butter Peptides and the Hydrophobicity of the Amino Acid or Peptide Moiety of O-Aminoacyl Sugars.

(4) Relationship between the bitterness of $O$ aminoacyl sugars and the hydrophobicity of the amino acid or peptide moiety

Since we obtained a result which suggested that the bitterness receptor recognizes the hydrophobicity of bitter compounds, we decided to study the relationship between the bitterness and hydrophobicity of a bitter compound by using $O$-aminoacyl sugars. We plotted the hydrophobicity of the amino acid or peptide residues in $O$-aminoacyl sugars along the $\mathrm{X}$ axis, and the logarithm of the threshold value along the $\mathrm{Y}$ axis (see Fig. 3). It is plausible to say that the relationship between the hydrophobicity of $O$-aminoacyl sugars and the logarithm of their threshold values can be described by an equation of the first order; i.e.

$$
\log T V=-0.333-0.143 H
$$

In Eq. (1), $T V$ means the threshold value (mM) and $H$ means the hydrophobicity $(\mathrm{kcal} / \mathrm{mol})$. We also calculated the coefficient of corre- 
lation and found this to be -0.693 . This result also shows that the bitterness of an $O$ aminoacyl sugar increases as the hydrophobicity increases.

\section{(5) Structure of the bitterness receptor}

In the previous paper, we proposed that the distance between two bitterness determinant sites should be around $4.1 \AA .{ }^{6}$ ) In this paper, however, we have shown that the bitterness receptor must have a site which determines the hydrophobicity of bitter molecules. Therefore, we propose the new bitterness receptor model which determines hydrophobicity shown in Fig. 4. This receptor is composed of two parts. First, the binding unit and stimulating unit of a bitter peptide is attached to two sites, this is a minimum requirement for bitterness production. Then, the receptor recognizes the hydrophobicity of the peptide and determine the bitterness potency. We thought that if $\mathrm{BU}$ and SU determinant sites were located at the bottom, and the hydrophobicity recognition zone was located on the wall of a pocket, our sys-

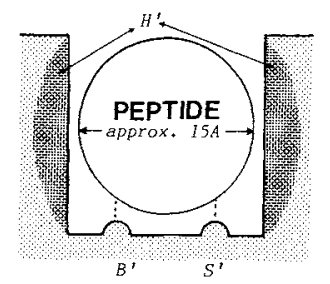

Fig. 4. Newly Proposed Bitterness Receptor Model. $B^{\prime}$, receptor site corresponding binding unit (BU); $S^{\prime}$, receptor site corresponding stimulating unit (SU); $H^{\prime}$, hydrophobicity recognition zone. tem of bitterness recognition would be wellexplained.

We also estimated the size of such a "pocket" according to our sensory analyses of thousands of bitter peptides, Table VII showing the bitter potency of some of our synthetic peptides. Bitter potency increases largely when peptides are composed of less than eight amino acids. However, there were no major difference of bitter potency when the peptides were composed of more than seven amino acids. These peptides form a ball-like shape instead of a helix conformation because they contain proline. We built molecular models of these peptides, and found that if the peptides were larger than $15 \AA$, the bitter potency did not increase greatly. Therefore, we conclude that the size of the "pocket" of the bitterness receptor should be around $15 \AA$.

We thus propose a mechanism for the bitter potency of peptides. As we reported in the previous paper, ${ }^{6)}$ two bitterness determinant sites (BU and SU) have to be at the proper distance first. Then, the bitterness receptor recognizes the hydrophobicity of a peptide, and various bitter potencies are exhibited. We believe that our findings can be applied to the taste design of several fermented products, which often include bitter peptides as an unexpected taste factor. Furthermore, our results could be of great help for studying taste receptors. By employing our results, for example, a labeling compound for the bitter taste receptor can be easily prepared. We have proposed some ideas about the structure of

Table VII. Bitter Potency of Synthetic Peptides

\begin{tabular}{|c|c|c|}
\hline Compound & $T V(\mathrm{~mm})^{a}$ & $R_{\text {caf }}^{b}$ \\
\hline Arg-Pro-Phe-Phe & 0.04 & 25 \\
\hline (Arg-Pro-Phe-Phe) ${ }_{2}$ & 0.01 & 100 \\
\hline (Arg-Pro-Phe-Phe) ${ }_{3}$ & 0.01 & 100 \\
\hline Arg-Gly-Pro-Pro-Phe-Ile-Val & 0.05 & 20 \\
\hline (Arg-Gly-Pro-Pro-Phe-Ile-Val) ${ }_{2}$ & 0.04 & 25 \\
\hline Arg-Gly-Pro-Phe-Pro-Ile-Ile-Val & 0.004 & 250 \\
\hline Pro-Val-Arg-Gly-Pro-Phe-Pro-Ile-Ile-Val & 0.004 & 250 \\
\hline Pro-Val-Leu-Gly-Pro-Val-Arg-Gly-Pro-Phe-Pro-Ile-Ile-Val & 0.015 & 67 \\
\hline
\end{tabular}

a Threshold value.

${ }^{b}$ Bitter taste potency by comparing with the threshold value of caffeine. $R_{\text {caf }}$ of caffeine is 1.0. 
both the bitterness and sweetness receptor in the previous report. ${ }^{16,17)}$ In order to prove our idea, we might have to synthesize the labeling peptides for the bitterness and/or sweetness receptor, and isolate the receptors. This study is now under-way and will be reported later elsewhere.

\section{References}

1) N. Ishibashi, Y. Arita, H. Kanehisa, K. Kouge, H. Okai and S. Fukui, Agric. Biol. Chem., 51, 2389 (1987).

2) N. Ishibashi, K. Sadamori, O. Yamamoto, H. Kanehisa, K. Kouge, E. Kikuchi, H. Okai and S. Fukui, Agric. Biol. Chem., 51, 3309 (1987).

3) N. Ishibashi, I. Ono, K. Kato, T. Shigenaga, I. Shinoda, H. Okai and S. Fukui, Agric. Biol. Chem., 52, 91 (1988).

4) N. Ishibashi, T. Kubo, M. Chino, H. Fukui, I. Shinoda, E. Kikuchi, H. Okai and E. Kikuchi, Agric. Biol. Chem., 52, 95 (1988).

5) N. Ishibashi, K. Kouge, I. Shinoda, H. Kanehisa and H. Okai, Agric. Biol. Chem., 52, 819 (1988).
6) S. Oyama, N. Ishibashi, M. Tamura, H. Nishizaki and H. Okai, Agric. Biol. Chem., 52, 871 (1988).

7) I. Shinoda, Y. Nosho, K. Kouge, N. Ishibashi, H. Okai, K. Tatsumi and E. Kikuchi, Agric. Biol. Chem., 51, 2103 (1987).

8) M. Tamura, K. Kinomura, M. Tada, T. Nakatsuka, H. Okai and S. Fukui, Agric. Biol. Chem., 49, 2011 (1985).

9) M. Tamura, M. Shoji, T. Nakatsuka, K. Kinomura, H. OKai and S. Fukui, Agric. Biol. Chem., 49, 2579 (1985).

10) J. Barrolier, Naturwissenschaften, 48, 554 (1961).

11) G. Pataki, J. Chromatogr., 12, 541 (1963).

12) Y. Nozaki and C. Tanford, J. Biol. Chem., 246, 2211 (1971).

13) N. Minamiura, Y. Matsumura, J. Fukumoto and $T$. Yamamoto, Agric. Biol. Chem., 36, 588 (1972).

14) N. Minamiura, Y. Matsumura and T. Yamamoto, $J$. Biochem. (Tokyo), 72, 841 (1972).

15) H. Fukui, H. Kanehisa, N. Ishibashi, I. Miyake and H. Okai, Bull. Chem. Soc. Jpn., 56, 766 (1983).

16) I. Shinoda and H. Okai, J. Agric. Food Chem., 33, 792 (1985).

17) M. Tamura, I. Shinoda, H. Okai and C. H. Stammer, J. Agric. Food Chem., 37, 737 (1989). 